\title{
LUTJANUS
}

p-ISSN: 0853 - 7658

e-ISSN: 2721-3757

https://ppnp.e-journal.id/lutjanus_PPNP

\section{Kajian Stabilitas Kapal Purse Seine Ukuran 30-50 Gt di Kabupaten Takalar Sulawesi Selatan}

\section{Stablity Study of Purse Seine Vessel Size 30-50 Gt In Takalar District,South Sulawesi}

\author{
Lendri $^{1}$, Husniati ${ }^{1)}$ \\ ${ }^{1}$ Jurusan Penangkapan Ikan Politeknik Pertanian Negeri Pangkajene Kepulauan
}

\author{
Article history: \\ received October 12, 2020 \\ Accepted Desember 15, 2020
}

\begin{tabular}{l} 
Keyword: \\
ship tability, purse seine, ship \\
design. \\
\hline *Corresponding Author: \\
mlendri@gmail.com \\
\hline
\end{tabular}

\begin{abstract}
Abstrak: Proses pembangunan kapal kayu di Kabupaten Takalar masih bersifat tradisional, pembangunan tersebut mempunyai kekurangan antara lain mengenai stabilitas kapal. Tujuan penelitian ini adalah menganalisis desain dan stabilitas kapal purse seine Takalar dalam tiga variasi muatan (kosong, setengah full dan kondisi penuh ikan). Penelitian ini dilakukan di kabupaten Takalar Provinsi Sulawesi Selatan pada bulan Maret- Oktober 2018 dengan melakukan pengukuran, pengamatan dan wawancara langsung di lapangan terkait dimensi utama dan stabilitas kapal. Parameter hidrostatis dilakukan dengan menggunakan formula naval architecture sedangkan analisis stabilitas menggunakan maxsufr yang selanjutnya dibandingkan dengan nilai acuan. Hasil analisis menyimpulkan bahwa nilai rasio dimensi utama kapal purse seine yang dibangun di Takalar tidak sesuai dengan nilai acuan, sehingga diperlukan redesain ukuran utama kapal, setelah redesain dilakukan, maka nilai stabilitas kapal purse seine telah sesuai dengan standar International MaritimeOrganitation.
\end{abstract}

Abstract: The process of building a wooden ship in Takalar districts is still traditional, the development has disadvantages such as the stability of the ship. The purpose of this study was to analyze the design and stability of purse seine ship in three cargo variations (empty, half full and full fish conditions). This research was conducted in Takalar district of South Sulawesi Province in March until October 2018 with performing measurements, observations and direct interviews in the field regarding the main dimensions and stability of the ship. The hydrostatic parameters are carried out using the naval architecture formula while the stability analysis uses maxsuf which is then compared with the reference value. The analysis concluded that the raslo values of the main purse seine ship built in Bulukurmba were not as appropriate as the reference values, so redesigning the main size of the ship was needed, after the redesign was done, the stability of the purse seine ship had complied with the International Maritime Organization standard.

\section{PENDAHULUAN}

Purse seine yang terdapat di Sulawesi Selatan memberikan keuntungan terbesar diperoleh untuk unit penangkapan (Husni, 2005). Kapal purse seine di kabupaten Takalar terbuat dari kayu dan di bangun secara tradisional yang memiliki sejumlah keunikan jika dibandingkan dengan kapal ikan dengan material baja. Keunikan diantaranya kapal dibangun tanpa menggunakan rencana garis (linesplan) sebagaimana layaknya kapal yang dibangun oleh perusahaan galangan kapal. Kapal ikan yang terbuat dari kayu yang dibangun di Sulawesi Selatan berdasarkan kepiawaian oleh para pengrajin yang diperoleh secara turun-temurun, ciri 
khasnya adalah karakter kapal kayu memiliki lunas (centre keel) yang relative besar (di atas rata-rata).

Kabupaten Takalar merupakan salah satu kabupaten yang terdapat di Provinsi Sulawesi Selatan yang memiliki armada purse seine yang cukup banyak. Pembuatan kapal purse seine masih bersifat tradisional dan keahlian mereka dari turun temurun. Perencanaan pembuatan kapal merupakan hal yang sangat penting dilakukan karena berdampak pada kemampuan kapal dan berpengaruh terhadap stabilitas kapal saat beroperasi. Wahyono (2011) menyebutkan bahwa sebagian besar pengrajin kapal di Indonesia melakukan pembangunan kapal diawali dengan pemasangan papan lambung baru kemudian kerangka sehingga terjadi kemungkinan kapal tidak simetris dan akan berpengaruh terhadap kelaik- lautan kapal.

Penelitian yang berkaitan dengan Desain dan stabilitas kapal purse seine yang pernah dilakukan antara lain; Lendri (2013). Kajian stabilitas statis kapal purse seine di kabupaten Takalar Sulawesi Selatan, Lendri (2014) Kajian stabilitas statis kapal purse seine di kabupaten Barru, Sulawesi Selatan, Hery et al. (2013) Tata muatan dan variasi musim penangkapan pengaruhnya terhadap stabilitas purseseiner Takalar Sulawesi Selatan. Penelitian tersebut hanya mengukur/mengkaji stabitas kapal purse seinetanpa melakukan redesain ukuran utama untuk mendapatkan ukuran utama yang optimal.

Oleh karena itu, penelitian ini mengkaji stabilitas kapal purse seine yang di bangun di kabupaten Takalar berdasarkan tiga kategori yaitu kategori kapal dalam keadaan kosog (menuju ke fishing ground), kapal setengah bermuatan (melakukan operasi penangkapan ikan), dan muatan full (pada saat kembali ke fishing ground). Adapun yang menjadi tujuan dalam penelitian ini adalah menganalisis desain kapal purse seine Takalar dan stabilitas kapal purse seine Takalar berdasarkan tiga kondisi/keadaan.

\section{METODE}

\section{Waktu dan Tempat}

Penelitian ini dilakukan di Kabupaten Takalar Provinsi Sulawesi Selatan pada bulan MaretJuni 2018.

\section{Alat dan Bahan}

Bahan utama penelitian yang digunakan adalah lima unit kapal purse seine di Kabupaten Takalar yang memiliki ukuran maksimal 50GT Alat untuk pengambilan data lapang adalah roll meter (50 meter), penggaris, bandul, waterpass dan alat tulis menulis. Adapun alat untuk pengolahan data yaitu satu set alat gambar teknik untuk menggambar lines plan dan general arrangement kapal, komputer dan software maxsurfuntuk menganalisis stabilitas kapal.

\section{Metode Pengumpulan Data}

Pengumpulan data primer dilakukan dengan cara mengukur ulang kapal yang telah selesai dibangun, pengamatan dan wawancara dengan pemilik kapal. Dimensi yang diukur adalah dimensi utama kapal yaitu LOA (Lenght Over All), LWL (Lenght of Water Line), LBP (Lenght Between Perpendicullars), (Breadth Moulded) atau B, D (depth), d (draft), kelengkungan.

\section{Analisis Data}

Data yang telah diperoleh dianalisa sesuai dengan ketentuan pembangunan kapal, adapun rincian olah data sebagai berikut, menghitung perbandingan rasio dimensi utama kapal $(L / B$, $L / D$ dan $B / D$ ), dan rasio dimensi utama kapal dari lima kapal sampel. Dari kelima kapal sampel tersebut, kita memilih satu kapal yang sesuai/yang mendekati nilai acuan yang dikeluarkan oleh Pujiati (1995) apabila kapal sampel tersebut memiliki nilai rasio dimensi utama tidak 
sesuai dengan nilai acuan, maka dilakukan redesain ukuran utama kapal yang mengikuti kaidah Fyson (1985). Berdasarkan gambar lines plan, selanjutnya menghitung nilai parameter hidrostatis kapal dengan menggunakan formula naval architecture seperti yang dikemukakan dalam Fyson (1985). Selanjutnya berdasarkan gambar general arrangement, dilakukan simulasi tata muatan pada beberapa kondisiStabilitas kapal dianalisis berdasarkan nilai parameter stabilitas kapal yang kemudian dibandingkan dengan nilai rekomendasi kriteria stabilitas. Ilustrasi rekomendasi kriteria stabilitas berdasarkan Derrett (2006), kurva stabilitas statis sebuah kapal berisikan nilai lengan pengembali (GZ) yang diplotkan terhadap suatu kemiringan (Gambar 1).

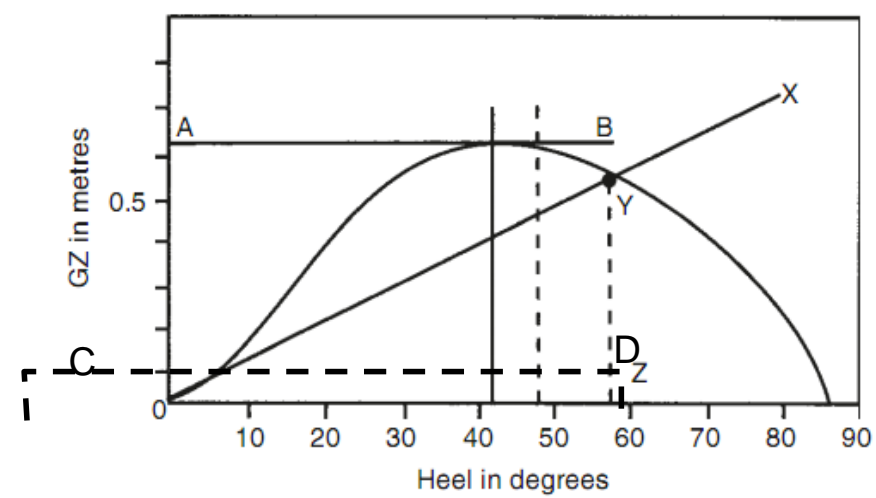

Gambar 1 Stability curva Statis(Kurva GZ)

(Sumber : Barras dan Derret, 2006)

\section{HASIL DAN BAHASAN \\ Desain Kapal}

Lima kapal sampel hanya satu yang mendekati nilai acuan yaitu KM Minasate'ne sesuai dengan Tabel 1, hal ini sesuai dengan penelitian Lendri (2013) yang mengatakan rasio dimensi utama kapal purse seine buatan Takalar sebagian tidak memenuhi nilai acuan standar, hal ini disebabkan oleh karena (1) pembuat kapal purse seine masih menggunakan metode trandisional, dalam artian mereka belum memulai pembuatan kapal tersebut dengan perencanaan yang sesuai dengan ilmu perkapalan, mereka membangun kapal tanpa desain, namun mereka membangun kapal berdasarkan pengalaman mereka turun temurun

Tabel 1. Size of the main dimensions of the sample Purse seine Vessel In Takalar

\begin{tabular}{clccccccc}
\hline No & Nama Kapal & $\mathbf{L}(\mathbf{m})$ & $\begin{array}{c}\mathbf{B} \\
(\mathbf{m})\end{array}$ & $\mathbf{H}(\mathbf{m})$ & $\begin{array}{c}\mathbf{T} \\
(\mathbf{m})\end{array}$ & $\mathbf{L} / \mathbf{B}$ & $\mathbf{B} / \mathbf{H}$ & $\mathbf{L} / \mathbf{H}$ \\
\hline 1 & KMS. Matoanging & 16 & 3,45 & 1,01 & 0.44 & 4,63 & 7,84 & 36,36 \\
2 & KMN. Minasate'ne & 24.6 & 4.6 & 1.55 & 1.25 & 5.35 & 2.97 & 12,3 \\
3 & KM. Bintang Timur & 14.6 & 3,67 & 1 & 0.62 & 3,97 & 5,91 & 23,54 \\
4 & KM. Harapan Baru & 21 & 4,65 & 1.75 & 1.15 & 4,51 & 4,04 & 18,26 \\
5 & KMS. Garuda Jaya & 21.1 & 4,16 & 1,53 & 1,23 & 4,39 & 4,16 & 18,12 \\
\hline
\end{tabular}

Ukuran utama KM. Minasate'ne yang baru (redesain) yaitu ukuran Panjang $=24$ meter, Lebar $=4,4$ meter dan dalam/tinggi $=1,9$ meter. 
Redesain ini dilakukan untuk mendapatkan pemanfaatan yang maksimum dan menambah kekuatan memanjang dan kecepatan kapal yang semakin tinggi, selain itu penambahan Tinggi (H/D) untuk mendapatkan penambahan volume ruang-ruang di bawah lantai deck seperti palka hasil tangkapan dan ruang mesin. Palka ikan yang lebih besar memungkinan akan adanya penambahan hasil tangkapan, mengingat alat tangkap purse seine merupakan alat tangkap yang produktif (Novita, et al. 2016)

KMN. Minasete'ne merupakan kapal purse seine yang beroperasi di perairan Sulawesi Selatan, kapal tersebut beroperasi selama 6-10 hari per-trip, sehingga diperlukan model kapal yang cocok dengan peruntukkannya, adapun model tersebut tergambarkan di lines plans KM. Minasete'ne, line plans tersebut merupakan hasil redesain. Lines plan merupakan rencana garis desain kapal yang dibuat pada masing-masing water line dan diproyeksi menjadi tiga bagian gambar yaitu : 1. Bagian depan (body plan), bagian samping (profile plan), dan ke-3 tampak atas (half breadth plan) (gambar 2)
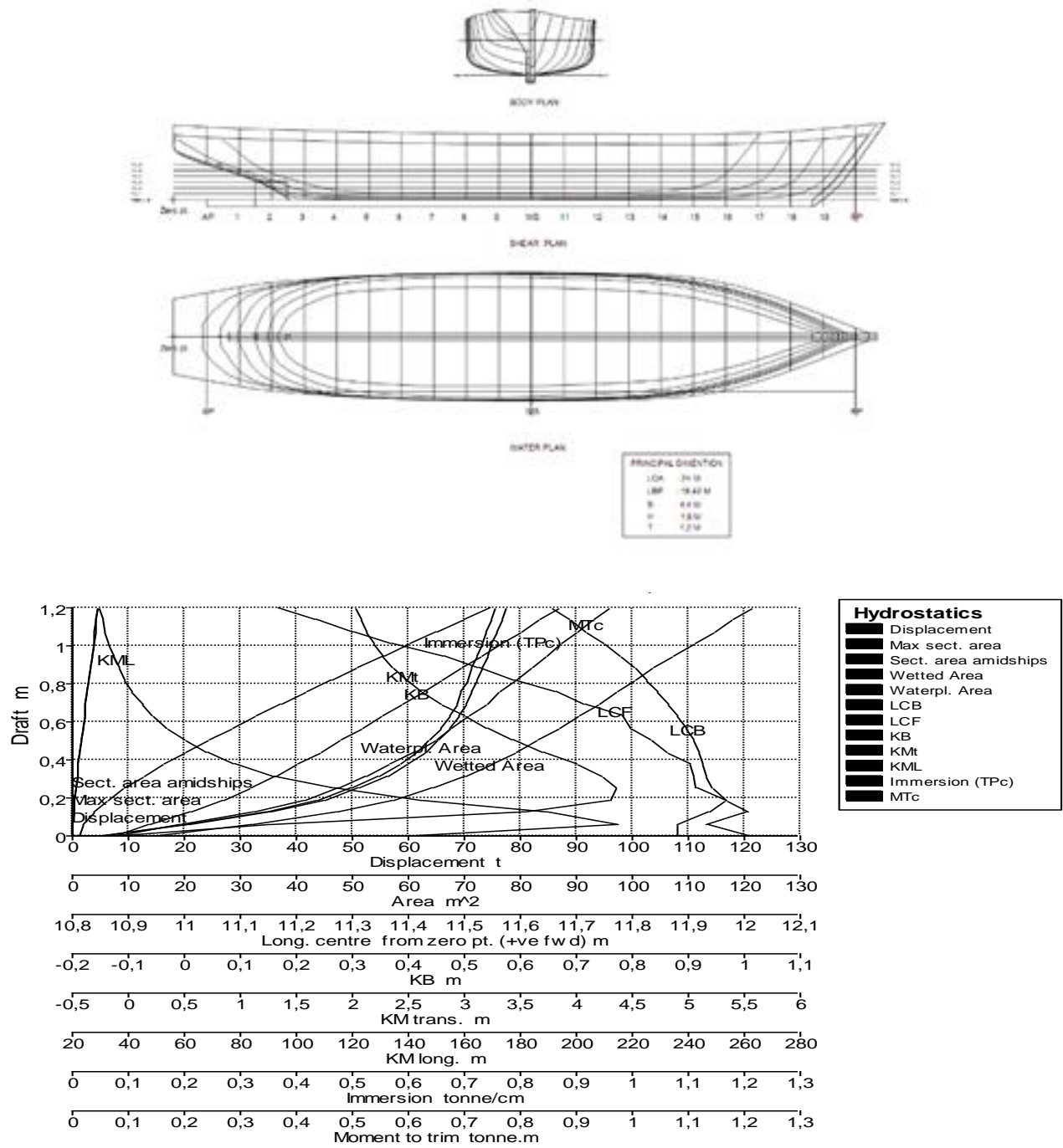

Gambar 3. Parameter hydrostatic 
Berdasarkan lines plan dapat disimpulkan bahwa Secara umum Purse seine yang ada di Takalar memiliki bentuk badan $V$ - bottom pada bagian haluan. Pada bagian midship hingga buritan memiliki bentuk badan kapal yaitu, Round bottomhal ini sesuai dengan karakteristik kapal purse seine yaitu harus mempunyai kecepatan yang sangat tinggi, stabitas yang sangat baik, sehingga bentuk badan $V$ - bottom, bagian midship hingga buritan memiliki bentuk badan kapal Round bottom hal ini juga sesuai dengan penelitian Novita dan Iskandar (2008) mengemukakan bahwa nilai tahanan gerak yang dimiliki oleh kasko model round bottom lebih kecil dibanding dengan kasko model round flat bottom, U-bottom maupun akatsuki, hal ini juga telah dikemukan oleh Heri (2013) bentuk badan kapal membentuk $V$ - bottom.

Parameter hidrostatis merupakan nilai yang menggambarkan keragaan kapal secara statis yang terdiri dari nilai volume displacement $(V)$, ton displacement $(\Delta)$, water plan area $\left(\mathrm{A}_{\mathrm{w}}\right)$, mindship area $\left(\mathrm{A}_{\mathrm{o}}\right)$, coefficient of fineness $\left(\mathrm{C}_{\mathrm{b}}, \mathrm{C}_{\mathrm{p}}, \mathrm{C}_{\mathrm{vp}}, \mathrm{C}_{\mathrm{o}}, \mathrm{C}_{\mathrm{w}}\right)$ ton per centimetrer immersion (TPC), Longitudinal centre of buoyancy (LCB), jarak maya pusat gaya apung (KB), jari-jari metacentre vertical (KM) dan longitudinal (KML). Nilai-nilai tersebut diperoleh berdasarkan nilai dari offset kapal purse seine. Tujuan nilai Hidrostatis adalah untuk memberikan gambaran perubahan nilai hidrostatis setiap garis air kapal (draft). Nilai hidrostatis dapat lihat pada gambar 3. Berdasarkan gambar tersebut dapat disimpulkan bahwa secara umum nilai-nilai dari parameter hidrostatis cenderung meningkat seiring dengan penambahan draft. Hal ini ini terjadi karena dengan bertambahnya draft kapal, maka luasan kapal yang terendam di dalam air semakin besar, sehingga menyebabkan nilai hidrostatis semakin besar (Purwanto et al, 2010). Nilai berat badan kapal (ton displacement). Pada kondisi draft maksimum berat badan kapal sebesar 74,81 ton

Penambahan tinggi draft kapal mempengaruhi nilai waterplan area, pada kapal purse seine nilai waterplan area meningkat seiring dengan penambahan tinggi draft, hal ini berat dalam menempatkan muatan secara horizontal nilai tersebut pada kondisi maksimum sebesar 0,72 Mindshiparea kapal merupakan nilai yang menunjukkan luas irisan melintang bagian tengah kapal purse seine secara melintang bagian tengah kapal, adapun nilai Mindship kapal sampel yaitu 1,25 


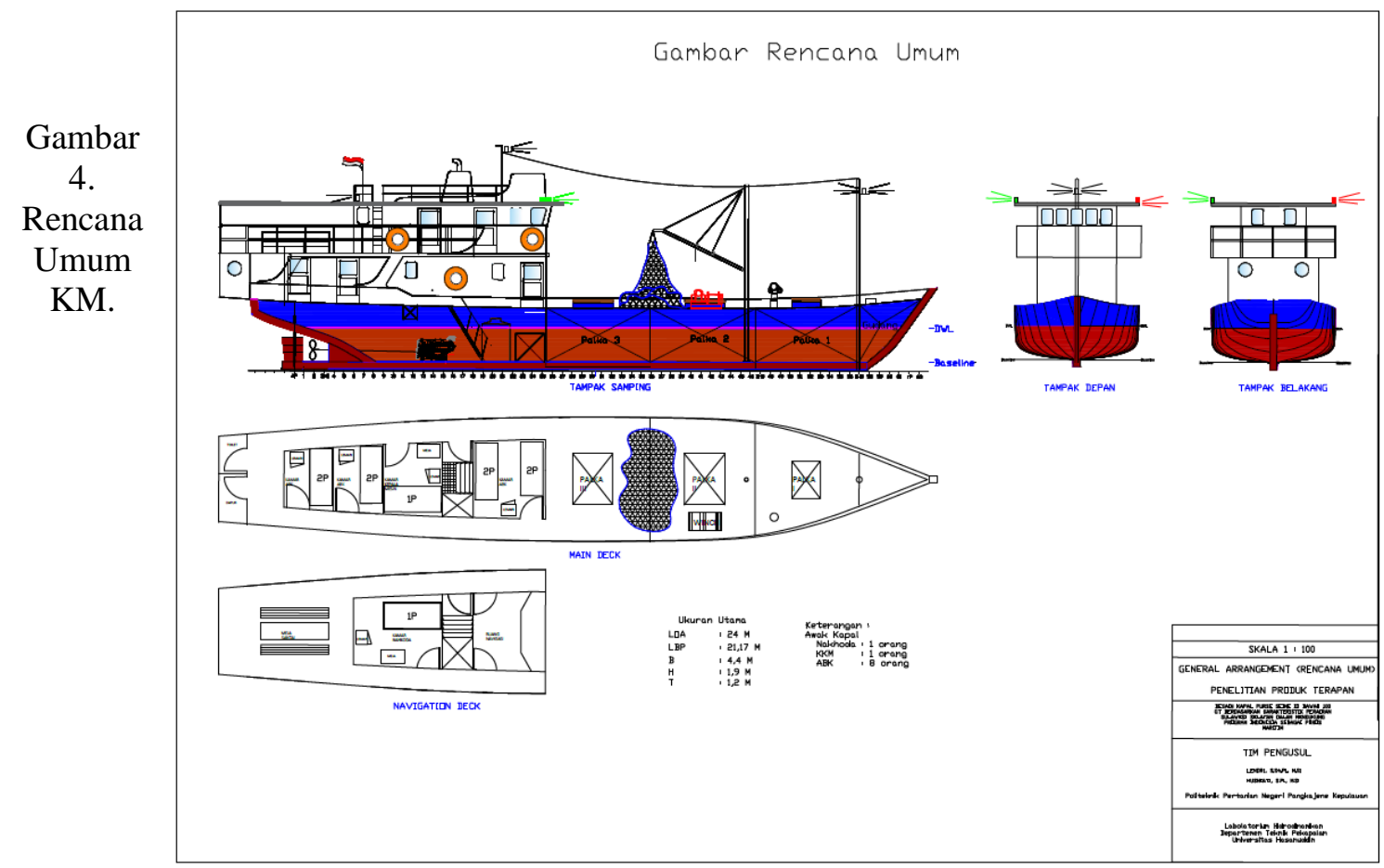

Minasate'ne

Nilai coefficient of fineness terdiri dari coefficient of block $(\mathrm{Cb})$, coefficient of prismatic $(\mathrm{Cp})$, coefficient of vertical prismatic $(C v p)$, coefficient of waterplan $(C w)$ dan coefficient of midship $(\mathrm{Cm})$. kapal purse seine dapat dilihat pada Tabel 2. Berdasarkan data pada Tabel 2 dapat dinyatakan bahwa kapal sampel purse seine sudah memenuhi standar

Tabel 2. Koefisien fineness KM. Minasate'ne

\begin{tabular}{lcc}
\hline \multicolumn{1}{c}{ Coefficient fineness } & Encircling gear Sampel & $\begin{array}{c}\text { Encircling gear } \\
\text { Indonesia }\end{array}$ \\
\hline Coefisien blok $(\mathrm{Cb})$ & 0,52 & $0,56-0,67$ \\
Coeffisien Prismatik $(\mathrm{Cp})$ & 0,72 & $0,60-0,79$ \\
Coeffisien waterplane $(\mathrm{Cw})$ & 0,78 & $0,78-0,88$ \\
Coeffisien mindship $(\mathrm{Ca})$ & 0.87 & $0,84-0,96$ \\
\hline
\end{tabular}

tiga kondisi, kondisi (I). Kapal menuju ke fishing ground dengan kriteria BBM penuh, logistic full, alat tangkap, ABK lengkap, es 19,761 ton dan air tawar 100\%, hasil tangkapan $0 \%$, kondisi (II), kapal sedang melakukan operasi penangkapan, dengan kriteria, bbm $70 \%$, logistic $70 \%$, total berat muatan=27,66ton, air tawar $70 \%$, es $90 \%=17,78$ ton, hasil tangkapan $50 \%$, kondisi (III) kapal kembali ke fishing base, kriteria bahan bakar 45\%, air tawar 30\%, pembekalan $30 \%$, muatan ikan $100 \%=19,761$ ton, Es $50 \%=9,88$ ton, total berat muatan 29,64ton.

Tabel 3. menunjukkan perubahan nilai KG sebuah kapal sampel, KG memberikan penjelasan tentang perubahan titik berat kapal seiring dengan perubahan distribusi muatan. Kondisi kapal I (menuju ke fishing ground) memiliki nilai $\mathrm{KG} 1,2 \mathrm{~m}$ dengan ton displacement 55,12 ton, kondisi II mempunyai ton displacement 62,22 ton dengan nilai KG 1,22, dan pada 
kondisi III dengan ton displacement 63,40 ton mempunyai nilai $\mathrm{KG} 1,25 \mathrm{~m}$. Nilai $\mathrm{KG}$ pada kondisi I sama dengan kondisi III yaitu 1,25 $\mathrm{m}$ hal ini disebabkan oleh distribusi muatan berpusat pada bagian haluan saja, (gambar 4). Derrett (1990) menjelaskan bahwa posisi titik berat $(\mathrm{G})$ tergantung dari muatan barang dan bobot lainnya di kapal, semua ini akan mempengaruhi stabilitas statis, karena merupakan salah satu faktor menentukan panjang lengan penegak GZ.

GZ atau lengan penegak adalah suatau daya yang ditimbulkan untuk mengembalikan kapal ke posisi tegak lurus, GZ ini yang menentukan apakah kapal itu mempunyai stabilitas positif atau stabilitas negative. Kurva GZ kapal sampel disajikan pada gambar 5, 6, dan 7. Hasil perhitungan dengan menggunakan software maxsurf, dari ketiga kondisi kapal (menuju ke fisihing ground), melakukan operasi penangkapan ikan, dan menuju kembali ke fisihing base, menunjukaan pada posisi I, nilai GZ sebesar $0,5 \mathrm{~m}$ dan nilai terbentuk pada sudut $34^{\circ}$, dan posisi II nilai GZ sebesar 0,45 dan nilai yang terbentuk $34,5^{\circ}$ dan pada kondisi III mempunyai nilai GZ 0,43m, nilai yang terbentuk yaitu 33,36 deg, sebagai momen penegak memperlihatkan hasil yang sesuai dengan acuan/standar IMO (t)

Melihat ketiga kondisi nilai GZ dan nilai luas area di bawah kurva GZ akan berubah jika terjadi perubahan distribusi muatan, nilai GZ dan nilai jarak antara titik G dan M (GM) mengecil pada saat ada penambahan muatan, hal ini dapat dilihat dari perubahan GM pada kondisi I, kondisi II, dan kondisi III, nilai GM yang terkecil terdapat pada kondisi III, nilai GM dapat di lihat pada tabel 3 akan tetapi nilai GM tersebut tidak menyebabkan kapal sampel mempunyai stabitas negative (nilai GZ masih sesuai dengan standar IMO).

Nilai GZ setiap kondisi variasi berbeda satu sama lainnya, nilai GZ terendah terdapat pada kondisi kapal menuju ke fishing base yaitu $0,43 \mathrm{~m}$ dan nilai GZ tertinggi terdapat pada kondisi kapal menuju ke fishing ground yaitu $0,47 \mathrm{~m}$. Berdasarkan tabel 4, nilai vanishingstability angle merupakan sudut kemiringan kapal tanpa terjadinya nilai GZ yang negative. Nilai Vanishing angle 3 kondisi variasi sama $\left(80^{\circ}\right)$. Selang dimana nilai GZ adalah positif, biasanya berada pada selang sudut $0^{0}-90^{\circ}$, kapal akan kembali ke posisi semula setelah momen yang menyebabkan kemiringan hilang (Rawson dan Tupper, 1989).

Perubahan nilai ton displacement akan mempengaruhi nilai KG, namun tidak langsung menentukan penurunan dan kenaikan nilai KG. kondisi I mempunyai bobot 55 ton dengan nilai KG 1.03 m, sedangkan kondisi III lebih kecil $\mathrm{KG}=1$ mnamun hanya saja, perbedaan $\mathrm{KG}$ tersebut tidak terlalu mencolok, hal ini disebabkan karena penempatan muatan yang berawal berpusat pada bagian haluanMenurut (Iskandar, 2007 dalam Marjoni, 2010). Penempatan bobot atau muatan yang tinggi secara vertical pada kapal akan memberikan pengaruh besar terhadap perubahan nilai $\mathrm{KG}$, demikian sebaliknya.

Tabel 3. Ton displacement, KG, GM

\begin{tabular}{clllll}
\hline \multirow{2}{*}{ Kondisi muatan } & \multicolumn{3}{c}{ Distribusi berat } & Nilai & \\
\cline { 2 - 6 } & Muatan $(\%)$ & BBM (ton) & $\Delta$ ton & KG (m) & GM (m) \\
\hline I & 0 & 1,5 & 55.12 & 1.25 & 1,026 \\
II & 70 & 1,05 & 62.22 & 1,22 & 1,00 \\
III & 100 & 0,65 & 63,40 & 1,25 & 1,00 \\
\hline
\end{tabular}


Lendri et al., / Lutjanus 25 (2), 72-85 (2020)
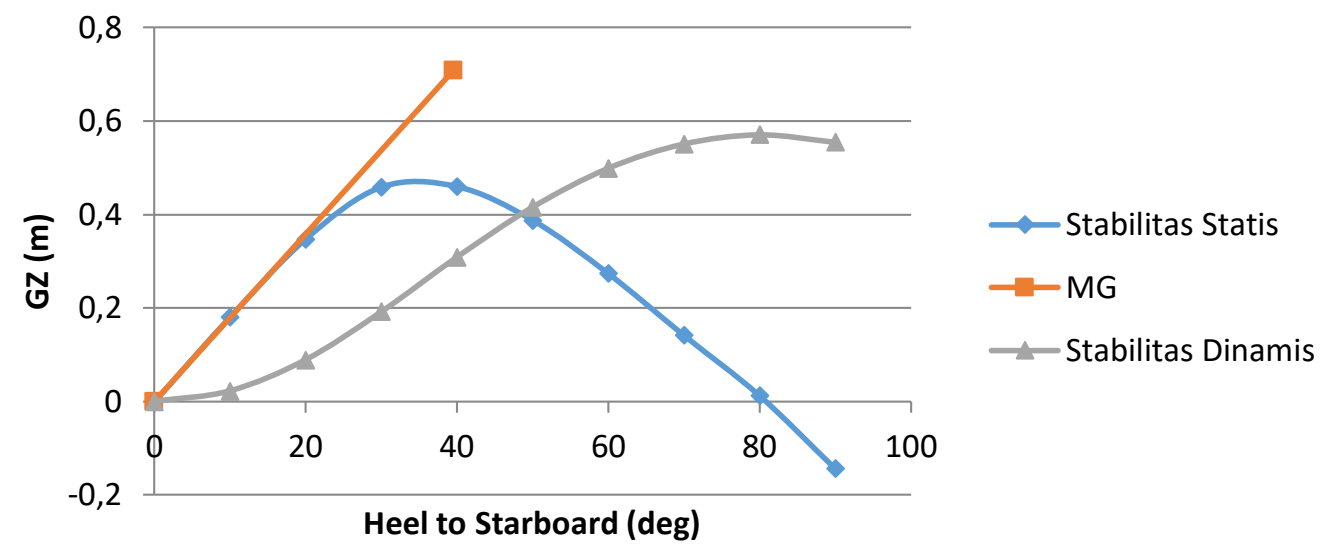

Gambar 5. Kurva Stabilitas KondisiI

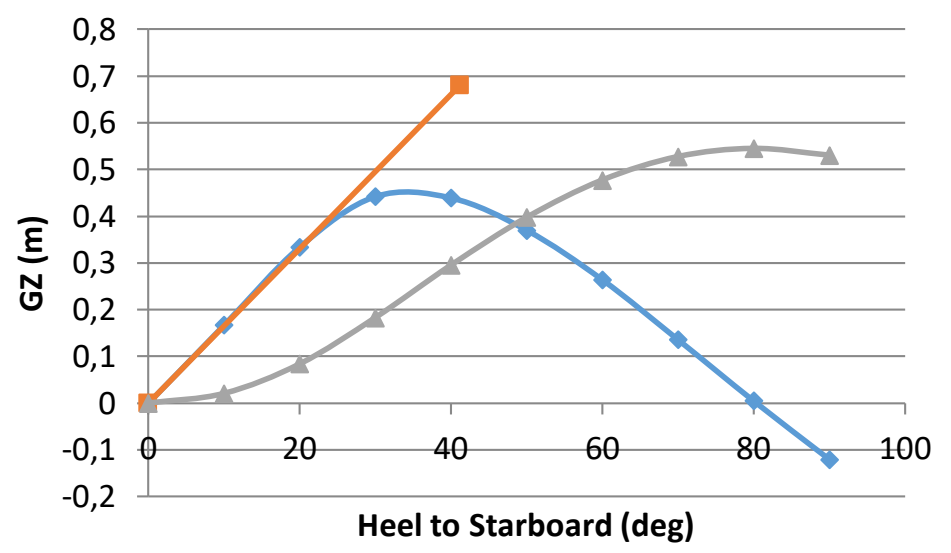

$\leadsto$ Stabilitas Statis

$-M G$

$\ldots$ Stabilitas Dinamis

Gambar 6. Kurva Stabilitas KondisiII

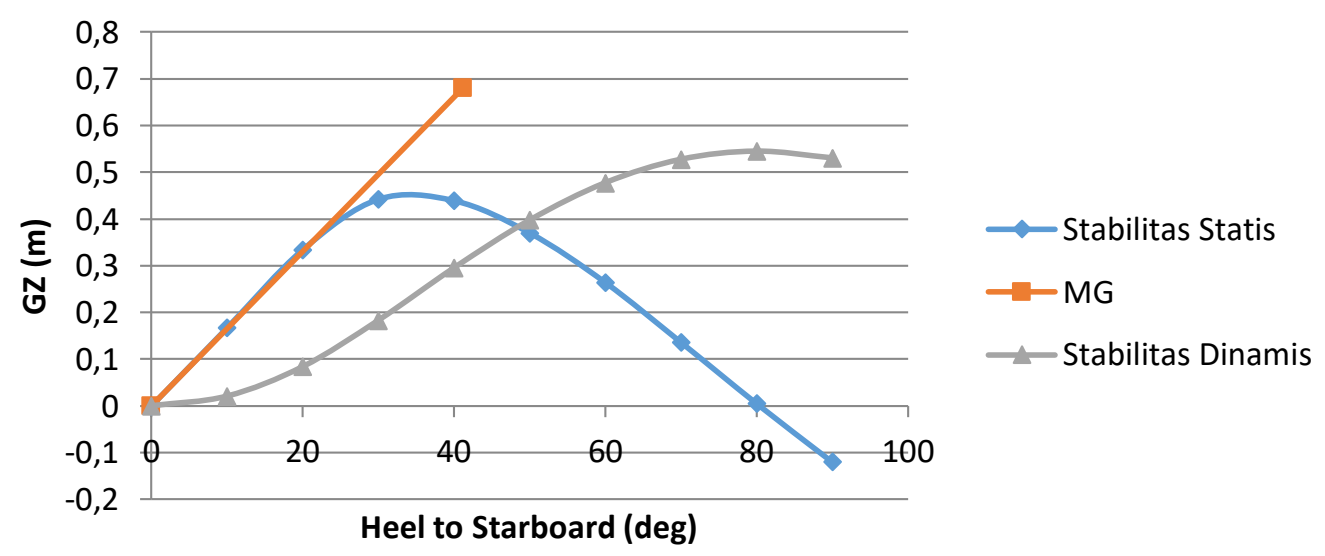

Gambar 7. Kurva Stabilitas KondisiIII 
Tabel 4. Kriteria Stabilitas Kapal Berdasarkan IMO (International Maritime Organization) Kondisi I (Menuju kefishing ground)

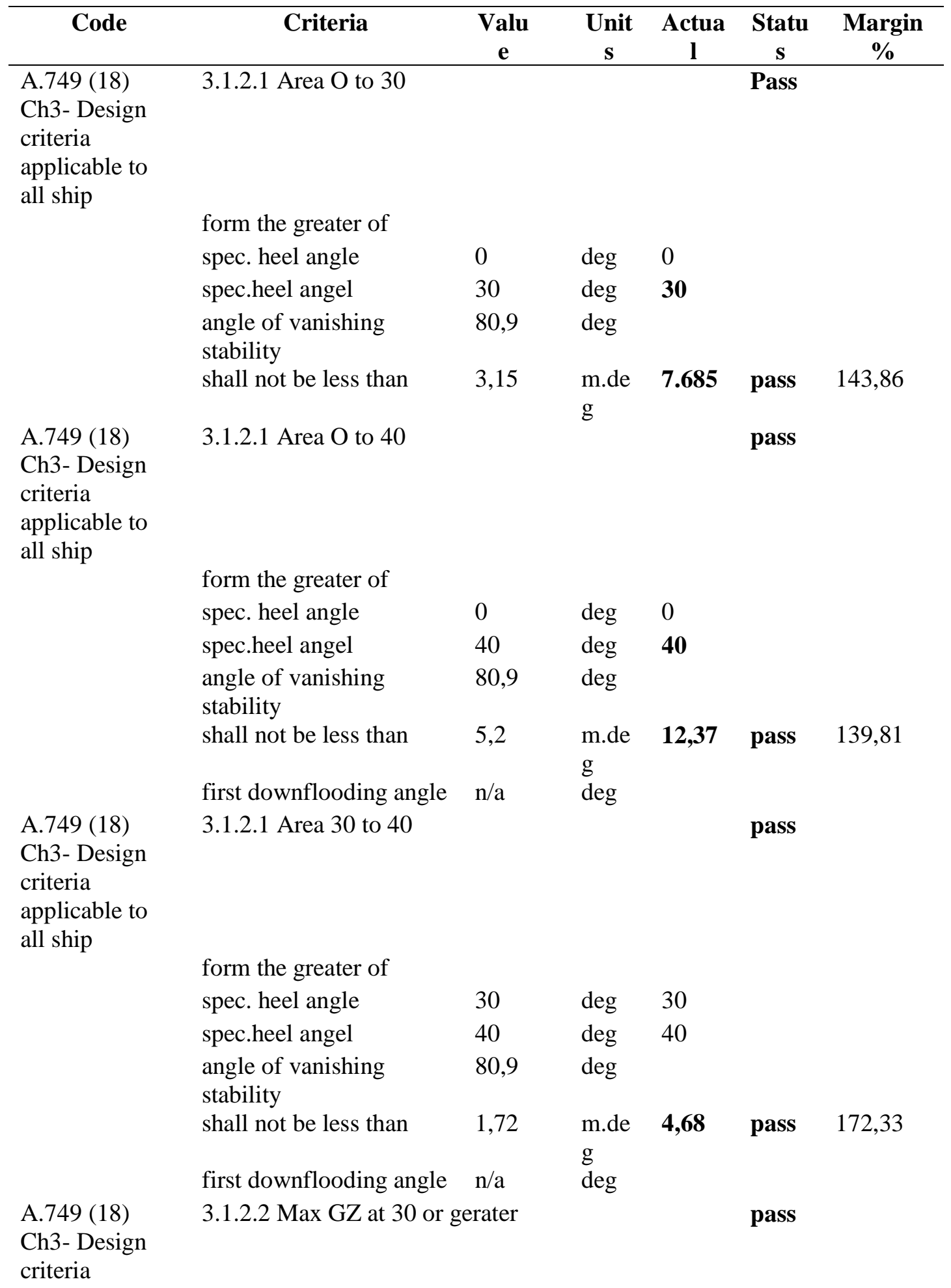


applicable to all ship

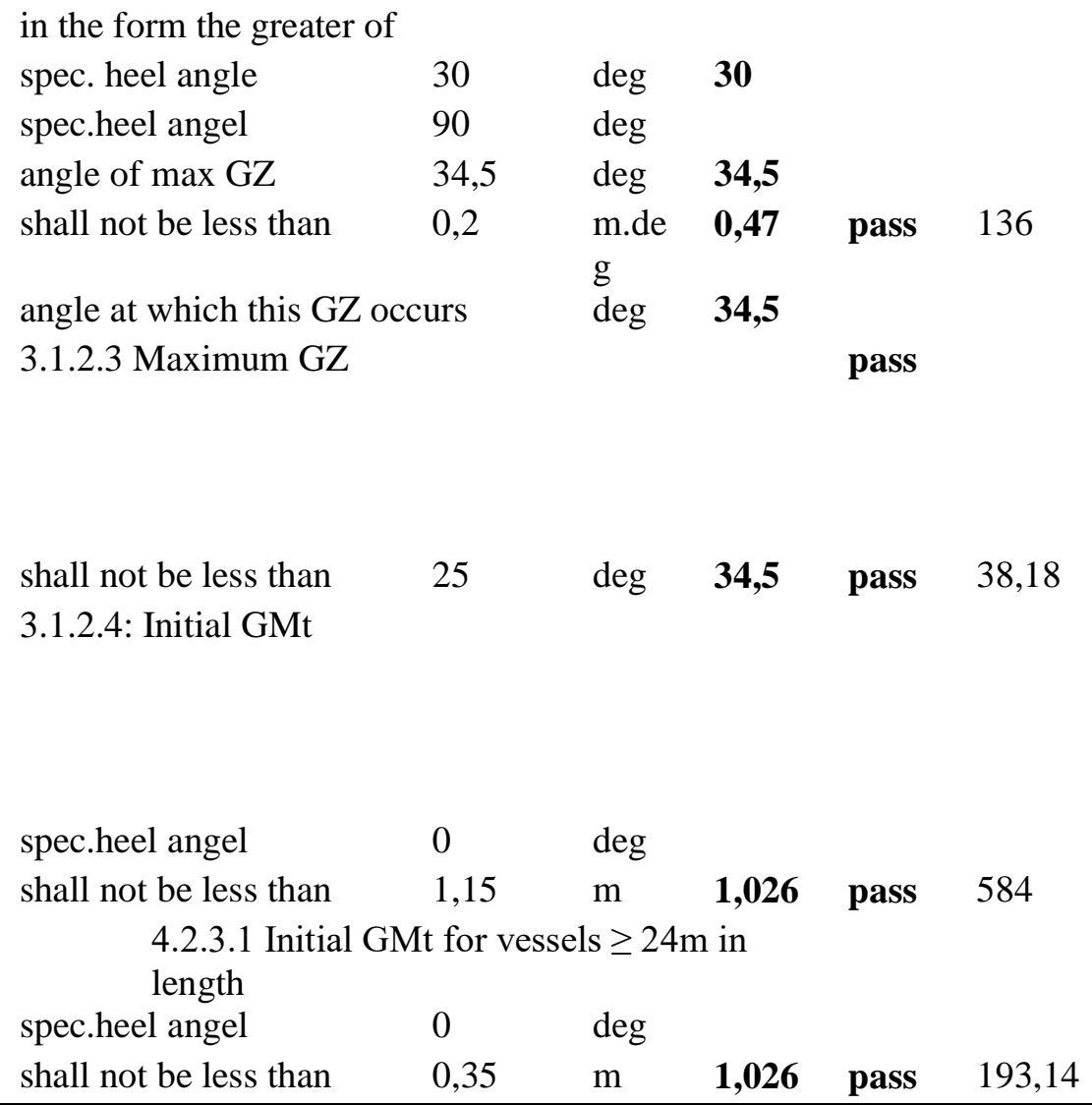

Kondisi II (operasi penangkapan ikan)

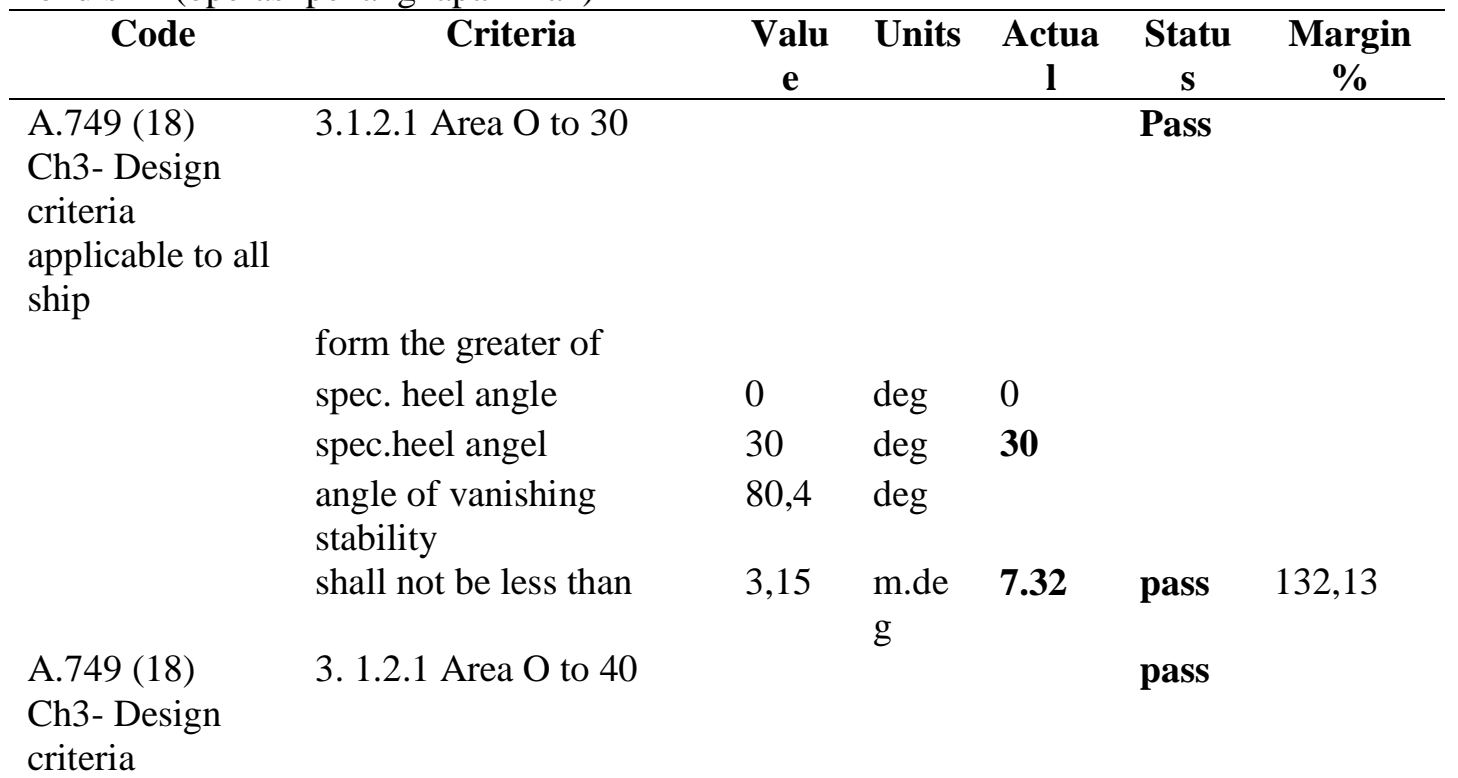


applicable to all

ship

A.749 (18)

Ch3- Design

criteria

applicable to all ship

A.749 (18)

Ch3- Design criteria

applicable to all ship

A.749 (18)

Ch3- Design

criteria

applicable to all ship

A.749 (18)

Ch3- Design

criteria

applicable to all ship

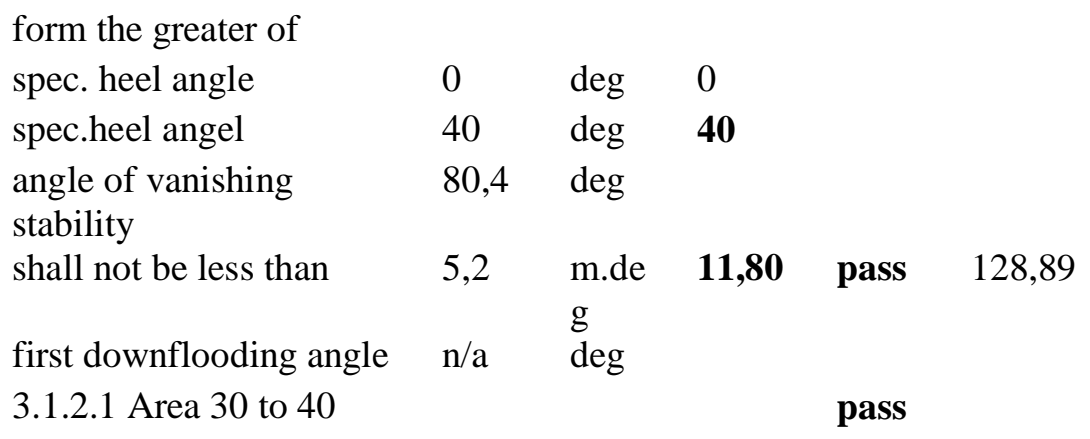


Lendri et al., / Lutjanus 25 (2), 72-85 (2020)

\begin{tabular}{lllllll} 
& $\begin{array}{l}\text { shall not be less than } \\
\text { 4.2 Fishing } \\
\text { vesse }\end{array}$ & 0,15 & $\mathrm{~m}$ & $\mathbf{0 , 9 5}$ & pass & 530,67 \\
& $\begin{array}{l}\text { 4.2.3.1 Initial GMt for } \\
\text { vessels } \geq 24 \mathrm{~m} \text { in length } \\
\text { spec.heel angel }\end{array}$ & 0 & & & & \\
& shall not be less than & 0,35 & $\mathrm{~m}$ & $\mathbf{0 , 9 5}$ & pass & 170,29 \\
\hline
\end{tabular}

Kondisi III (back tofishing base)

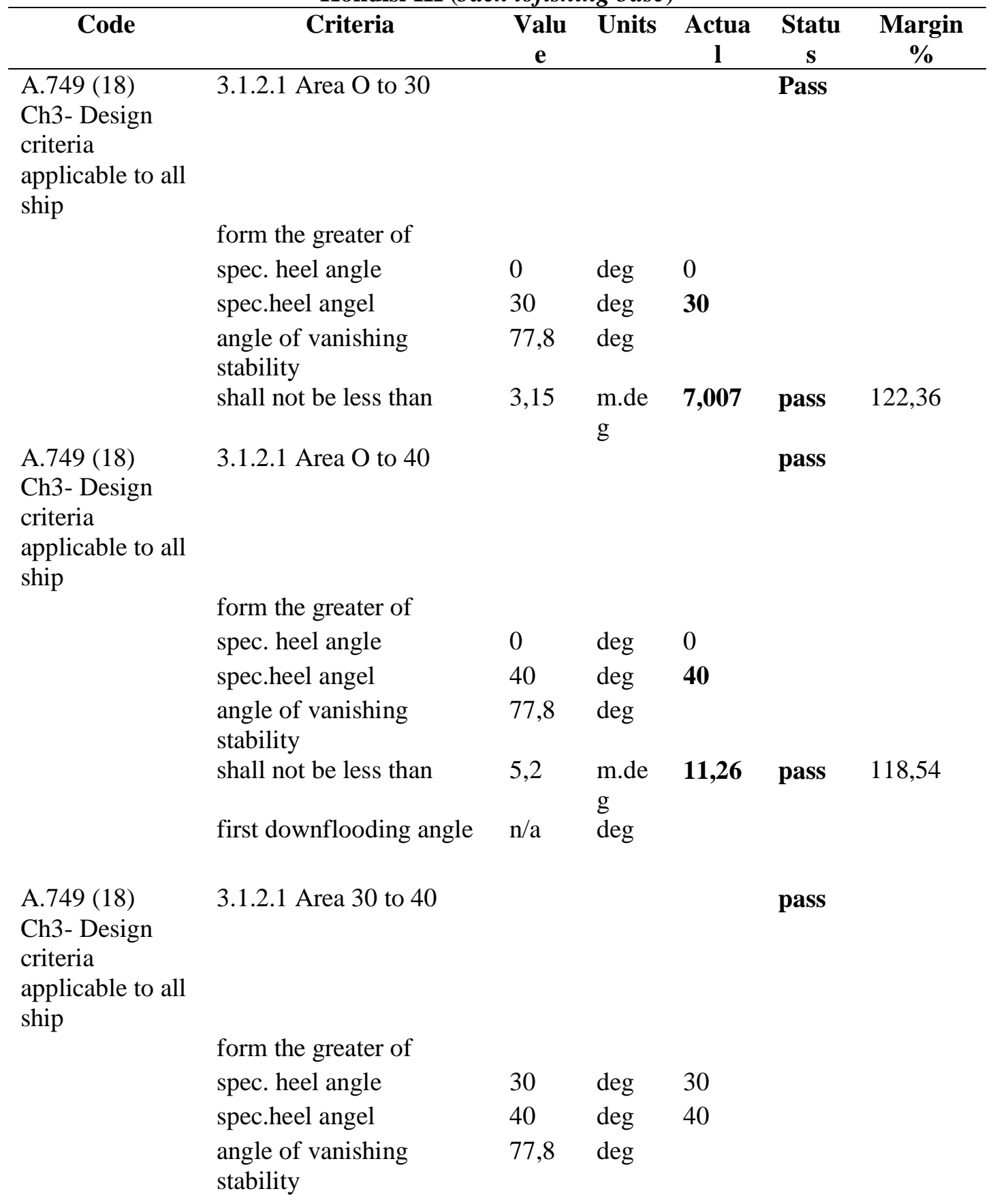




$\begin{array}{llllll}\text { shall not be less than } & \text { 1,72 } & \begin{array}{l}\text { m.de } \\ \mathrm{g}\end{array} & \mathbf{4 , 2 6} & \text { pass } & 147,94 \\ \text { first downflooding angle } & \mathrm{n} / \mathrm{a} & \begin{array}{l}\mathrm{deg} \\ \mathrm{n}\end{array} & \end{array}$
A.749 (18)
Ch3- Design
criteria
applicable to all
ship

3.1.2.2 Max GZ at 30 or gerater

pass

\section{A.749 (18) \\ Ch3- Design \\ criteria \\ applicable to all ship}

\section{A.749 (18) \\ Ch3- Design \\ criteria \\ applicable to all ship}

spec.heel angel

shall not be less than

in the form the greater of

spec. heel angle

spec.heel angel

$30 \quad$ deg $\quad 30$

angle of max GZ

shall not be less than

angle at which this GZ occurs

90 deg

3.1.2.4: Initial GMt

$0 \quad$ deg

33,6 deg $\mathbf{3 3 , 6}$

$0,2 \quad \mathrm{~m} \quad \mathbf{0 , 4 3}$

$\operatorname{deg} \quad \mathbf{3 3 , 6}$

pass 115,5

pass

25 deg $\mathbf{3 3 , 6}$ pass 34,54

$0,15 \mathrm{~m} \quad \mathbf{0 , 9 0 2}$ pass 501,33

4.2.3.1 Initial GMt for vessels $\geq 24 \mathrm{~m}$ in length spec.heel angel

shall not be less than

$0 \quad$ deg

$0,35 \mathrm{~m}$
0,902

pass

\section{KESIMPULAN}

Hasil penelitian menunjukkan bahwa bentuk badan kapal mulai dari haluan sampai mindship adalah V-Bottom, bentuk badan kapal mulai dari mindship ke buritan adalah Round bottom. Nilai parameter hidrostatis dan coefficient of finenesspada kapal sampel sudah memenuhi standar International Maritime Organitation (IMO). Nilai stabilitas kapal purse seine untuk tiga kondisi, kondisi kosong (menuju ke fishing ground), kondisi pada saat operasi penangkapan, dan kondisi full (menuju ke fishing base) setelah diredesain sudah memenuhi standar IMO 


\section{UCAPAN TERIMA KASIH}

Tulisan ini merupakan hasil penelitian Penelitian Strategis Nasional yang dibiayai oleh Direktorat Riset dan Pengabdian Masyarakat (DPRM) Kementrian Ristek dan Perguruan Tinggi Republik Indonesia.

\section{DAFTAR PUSTAKA}

International Maritime Organization. 1995. Code on Intact Stability For All Type of Ships Covered by IMO Instruments Resolution A. 749 (18).

Hery S, dkk. 2013. Tata Muatan dan Variasi Musim Penangkapan Pengaruhnya Terhadap Stabilitas Purse Seiner Takalar, Sulawesi Selatan. Marine Fisheries Jurnal Volume 4 No. 2 November 2013

Iskandar B.H. dan Pujiati S. 1995. Keragaan Teknis Kapal Perikanan di Beberapa Wilayah Indonesia [Laporan Penelitian]. Bogor (ID): Jurusan Pemanfaatan Sumberdaya Perikanan, Fakultas Perikanan, Institut Pertanian Bogor.

Lendri, 2013. Analisis Stabilitas Kapal Purse seine di Sulawesi Selatan. Jurnal Adiwidia Volume 3 No 1

Marjoni dkk. 2010. Stabilitas Statis dan Dinamis Kapal Purse seine di Peabuhan Perikanan Pantai Lampulo Kota Banda Aceh Nanggroe Aceh Darussalam. Marine Fisheries Volume 1 no 2 November 2010

Novita, Y, dan Iskandar, B.H. 2008. Hubungan Antara Bentuk Kasko Model Kapal Ikan Dengan Tahanan Gerak. Bulletin PSP 17(3): 315 - 324.

Novita,et al. 2016. Desain kapal Kapal Purse Seine Modifikasi di Kabupaten Bulukumba Provinsi Sulawesi Selatan. Jurnal Perikanan dan Kelautan Volume 6 Nomor 2

Susanto, A., Iskandar, B.H. dan Imron, M. 2011. Evaluasi Desain dan Stabilitas Kapal Penangkap Ikan di Palabuhanratu (Studi Kasus Kapal PSP 01). Marine Fisheries. 2(2): 213-221.

Wahyono, A. 2011. Kapal Perikanan (Membangun Kapal Kayu). Semarang: BPPI, Direktorat Jenderal Perikanan Tangkap, Kementerian Kelautan dan Perikanan. Fyson J. 1985. Design of Small Fishing Vessels. England: Fishing News Book Ltd - Farnham-Surrey. 